\title{
PENERAPAN METODE 360 DERAJAT DAN ANALYTICAL HIERARCHY PROCESS (AHP) DALAM SISTEM PENILAIAN KINERJA PEGAWAI (STUDI KASUS : RUMAH SAKIT FADILAH PRABUMULIH)
}

\author{
Suzi Oktavia Kunang', Agus Bayu Samsil ${ }^{2}$ \\ Dosen Fakultas Ilmu Komputer, Universitas Bina Darma ${ }^{1}$ \\ Mahasiswa Fakultas Ilmu Komputer, Universitas Bina Darma² \\ Jalan Jenderal Ahmad Yani 3 Palembang, Sumatera Selatan,30264 Indonesia ${ }^{1,2}$ \\ Su-rel: suzi_oktavia@binadarma.ac.id ${ }^{1}$, abayusamsil@gmail.com ${ }^{2}$
}

\begin{abstract}
Decision support System software is very useful in the assessment process of employee performance. This study implements a method known as method name 360 degrees. This method conducts feedback evaluation by combining various feedback obtained from coworkers, employees, subordinates, officers and company customers, results of the feedback assessment process will continue with the process Assessment by using the Analytic Hierarchy Process $(A H P)$ method which results in the decision by comparing the priority criteria so that the weight value of each criterion has been obtained by the decision. Are sorted from the largest value to the smallest. The results of the study obtained the performance value of employees in the company derived from the assessments given to all employees involved in the assessment.
\end{abstract}

Keywords: Decision Support System, 360 Degrees, Analytic Hierarchy Process (AHP)

\begin{abstract}
Abstrak : Perangkat lunak Sistem Pendukung Keputusan sangat bermanfaat pada proses penilaian kinerja pegawai. Penelitian ini menerapkan sebuah metode yang dikenal dengan nama Metode 360 Derajat. Metode tersebut melakukan evaluasi umpan balik dengan menggabungkan berbagai umpan balik yang diperoleh dari rekan kerja, atasa, bawahan, pegawai dan pelanggan perusahaan, Hasil proses penilaian umpan balik tersebut akan dilanjutkan dengan proses perhitungan penilaian dengan menggunakan Metode Analytic Hierarchy Process (AHP) yang menghasilkan keputusan dengan membandingkan kriteria-kriteria prioritas sehingga diperoleh suatu nilai bobot dari setiap kriteria yang dimiliki yang hasil keputusan diurutkan dari nilai terbesar samapai terkecil. Hasil penelitian diperoleh nilai kinerja pegawai di perusahaan yang diperoleh dari penilaian yang diberikan kepada seluruh karyawan yang terlibat dalam penialaian yang dilakukan.
\end{abstract}

Kata Kunci : Sistem Pendukung Keputusan, 360 Derajat, Analytic Hierarchy Process (AHP)

\section{PENDAHULUAN}

Perkembangan teknologi informasi yang sangat pesat dapat diimplemetasikan sebagai penunjang kegiatan kerja dalam menghasilkan informasi dalam proses pengambilan keputusan perusahaan, misalnya sistem pengambilan keputusan dalam menentukan Penilaian kinerja karyawan yang harus dilakukan untuk menilai kinerja dari setiap karyawan. Perusahaan.
Seringkali Proses penilaian kinerja yang dilakukan di perusahaan darasakan tidak efektif (deLeon \& Ewen, 1997). Proses penilaian kinerja yang dilakuan pihak perusahaan membuat sebagian besar karyawan tidak nyaman dan tidak puas (Kreitner \& Kinicki, 2001).

Efektifitas penilaian kinerja salah satunya dipengaruhi oleh penerimaan karyawan terhadap sistem penilaian yang berlaku di perusahaan (Tziner, Joanis, \& Murphy, 2000). Penghargaan dan promosi Karyawan sangat erat kaitannya 
dengan Penilaian kinerja sehingga jika dirasakan ketidak adilan dalam proses penilaian akan sangat mengganggu stabilitas karir seorang karyawan (Yamaguchi, 2005). Penurunan kepuasan kerja, komitmen pada organisasi, dan kecenderungan turn over yang tinggi dipengaruhi oleh Ketidak puasan karyawan terhadap sistem penilaian (Paré, Tremblay, \& Lalonde, 2004).

Proses penilaian kinerja karyawan sebaiknya melibatkan semua karyawan yang ada diperusahaan sehingga hasil evaluasi penilaian akan lebih membantu karyawan tersebut untuk menilai diri mereka sendiri sebagaimana karyawan lain disekitar mereka menilai mereka. Salah satu pendekatan dalam penilaian kinerja yang melibatkan beberapa elemen adalah penilaian kinerja 360 derajat. Instrument pada metode 360 derajad digunakan untuk mengukur perilaku kerja karyawan berdasarkan evalusi dari dua atau lebih sumber seperti manajer, rekan kerja serta bawahan (Beehr, Ivanitskaya, Hansen, Erofeev, \& Gudanowski, 2001).

Menurut (Fleenor \& Prince, 1997) pada (Ali Hasan, SMn. \& Universitas, 2013) memaparkan bahwa sisi positif (benefits) dari metode 360 derajat ini adalah: 1) Memberikan perspektif baru dalam menilai perilaku, kemampuan , keterampilan serta kinerja setiap individu; 2) Metode Umpan Balik 360 Derajat meminiailisir kesalahan dalam proses penilaian yang sering menggunakan metode penilaian dengan satu sumber; 3) Penilaian dengan Metode Umpan Balik 360 Derajat memberikan kesempatan kepada setiap individu karyawan menilai diri mereka sendiri.

Setiap perusahaan dalam menilai kinerja karyawan mereka sudah pasti memiliki kriteria tersendiri dalam proses penilaian kinerja karyawan, hal ini disesuaikan dengan target nilai yang ingin dicapai oleh setiap perusahaan, dengan banyaknya kriteria capaian ini akan menpersulit pihak manajemen perusahaan untuk memberi bobot penilaian pada setiap kriteria penilaian, oleh karena itu dibutuhkan sebuah sistem pendukung keputusan yang melibatkan semua karyawan dalam penilaian dan proses perhitungan berdasarkan kriteria-kriteria yang ditetapkan perusahaan sehingga diperoleh nilai perankingan yang sangat akurat. Berdasarkan hal ini peneliti memilih untuk melakukan perhitungan penilaian dengan menggunakan metode Analytical Hierarchy Process (AHP).

Pada penelitian ini dilakukan penggabungan Metode Multi-Rater Assessments (360-Derajat) yang merupakan metode umpan balik 360 derajat dan metode Analytic Hierarchy Process (AHP) dan menggunakan studi kasus Pada proses penilaian kinerja pegawai, di Rumah Sakit Fadhilah Prabumulih yang menghasilkan sebuah sistem perangkat lunak untuk mengukur kinerja Karyawan Rumah Sakit tersebut sehingga dengan penggabungan kedua metode tersebut mampu mendapatkan hasil penilaian dari seluruh karyawan yang terlibat di bagian tersebut menjadi suatu sistem informasi penilaian kinerja perawat yang akurat, cepat dan tidak terjadi perulangan pada penginputan data serta memberikan hasil perhitungan dengan metode yang ditampilkan dalam bentuk perankingan dengan cara mengurutkan hasil penilaian dari nilai terbesar hingga nilai yang terkecil, dari proses ini diperoleh sebuah sistem pengambilan keputusan untuk menentukan karyawan yang berkompeten berdasarkan hasil penilaian kinerja 
dari seluruh elemen yang terlibat dalam perusahaan yang nantinya akan meningkatkan kinerja organisasi perusahaan.

\section{METODE PENELITIAN}

\subsection{Tahapan Penelitian}

Tahapan metode penelitian dalam penyusunan penelitian ini ditunjukan pada gambar 1.

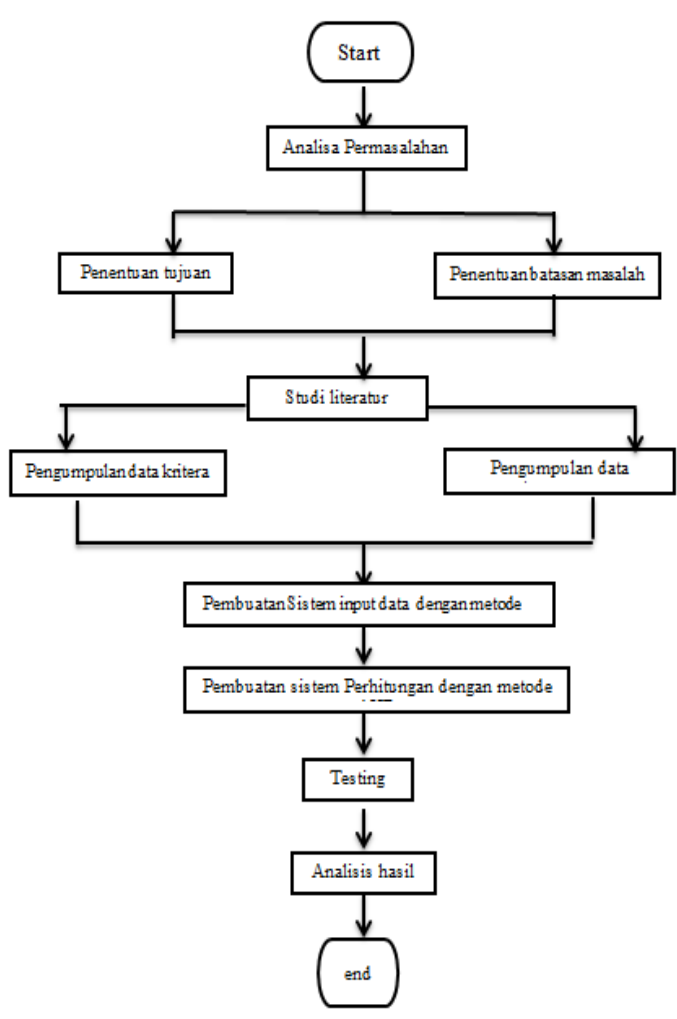

Gambar 1. Kerangka Kerja Penelitian

\subsection{Metode 360 Derajat}

Metode 360 derajat didefinisikan sebagai sebuah metode penilaian kinerja yang dilakukan oleh berbagai pihak sehingga menghasilkan nilai yang diharapkan lebih, adil, jujur, dan tepat sasaran dikarenakan semua karyawan yang terlibat dalam perusahaan memiliki kesempatan yang sama untuk memberikan penilaian bagi setiap individu yang memiliki hubungan kerja di perusahaan tersebut baik itu atasan, rekan kerja, mitra, anak buah, maupun pelanggan perusahaan tersebut.

Metode 360 derajat ini dapat digunakan untuk mendapatkan hasil penilaian dari seluruh karyawan yang terlibat di bagian tersebut dalam perusahaan. Pada proses penilaian dengan metode Multi-Rater Assessments, hasil penilaian yang diperoleh berdasarkan survey bersifat rahasia, hasil survey tersebut selanjutnya ditabulasikan kemudian dibagikan kepada pegawai yang dinilai dan dilakukan oleh manajer perusahaan (Linman, 2006).

Tahapan pelaksanaan penilaian kinerja dengan sistem penilaian metode umpan balik 360 derajat ini adalah sebagai berikut (Antonioni, 1996).

1. Mengembangkan kuesioner

Sisem skala dalam Kuesioner yang digunakan untuk sistem penilaian kinerja 360 derajat menggunakan sistem skala 1-4, sedangkan pertanyaan yang akan diajukan biasanya disesuaikan dengan dimensi yang berhubungan dengan job performance setiap pekerjaan (contoh: kerjasama dengan kelompok, kepemimpinan, inisiatif, komunikasi dll.).

2. Memastikan tingkat kepercayaan dari partisipan

Harus diambil beberapa langkah untuk bisa memastikan kepercayaan terhadap hasil yang diperoleh dari penggunaan metode 360 derajat tersebut, misalnya menutupi identitas dari si pemberi jawaban kustioner sehingga 
hasil penilaian tidak direkayasa. Hal ini akan memberikan nilai kepercayaan kepeda semua orang bahwa hasil yang diperoleh apa adanya sesuai dengan yang kinerja seseorang berdasarkan penilaian responden.

3. Menyediakan pelatihan atau orientasi Pelatihan dan orientasi untuk proses umpan balik dibutuhkan untuk kelancaran proses umpan balik tersebut. Dalam pelatihan dan orientasi ini, karyawan diperkenalkan dengan metode 360 derajat tersebut dan manfaat dari penggunaan metode 360 derajat tersebut dilaksanakan di organisasi atau perusahaan.

4. Pengawasan umpan balik dari kuesioner Mencantumkan instruksi yang jelas sehingga mencegah kesalah pahaman pada saat proses pengisian kuisioner

5. Analisis data

Analisis data meliputi hasil penilaian ratarata. Analisis yang dihasilkan berupa deskripsi dimensi kerja, deskripsi ruang lingkup kerja vs kinerja yang diharapkan oleh perusahaan, penilaian kinerja individual dan group atau divisi kerja dan peringkat organisasi, serta rekomendasi untuk pengembangan di masa yang akan datang. Analisis data dapat juga meliputi kelebihan serta kekurangan dari divisi dan organisasi yang nantinya akan mendukung rekomendasi pelatihan dan pengembangan organisasi.

6. Mengembangkan dan mendistribusikan hasil Hasil penilaian sebaiknya didiskusikan dengan karyawan terkait dengan pembahasan kinerja karyawan. Hasil penilaian yang dibahas dengan karyawan meliputi perbandingan antara, penilaian dari atasan, penilaian diri sendiri dan rata-rata penilaian dari pihak lain misalnya customers, rekan kerja.

Metode penilaian 360 derajat ini memiliki dampak positif jika di lakukan secara rutin yaitu:

1. Mendapat masukan dari berbagai pihak, sehingga akan lebih objektif dibandingkan jika hanya dari satu sumber.

2. Resiko terjadinya diskriminasi dan penilaian subjektif dalam penilaian kinerja dapat dikurangi.

3. Meningkatkan kerja sama di kalangan anggota tim, karena mereka saling meberikan penilaian satu sama lain erhadap kinerja masing-masing karyawan.

4. Dapat memahami kebutuhan pengembangan setiap individu maupun organisasi.

5. Adanya informasi yang akurat mengenai apa yang harus dilakukan untuk meningkatkan karir.

\subsection{Metode Analytic Hierarchy Process (AHP)}

Thomas L.Saaty adalah seorang ahli matematika memperkenalkan Metode Analytical Hierarchy proses (AHP) pada tahun 1971-1975 di Wartoon School (Thomas L Saaty, 1980), Metode AHP tersebut merupakan kerangka dalam mengambil keputusan yang efektif untuk menyederhanakan dan mempercepat proses pengambilan keputusan dalam persoalanpersoalan yang kompleks.

Model Analytical Hierarchy proses (AHP) ini merupakan salah satu model dalam sistem pengambilan keputusan (SPK), metode AHP ini 
merupakan sebuah hierarki fungsional yang input utamanya berupa persepsi seseoran, dengan adannya hierarki memungkinkan dipecahkan yang tidak terstuktur dan kompleks menjadi subsub masalah, yang kemudian disusun menjadi suatu bentuk hierarki (Kusrini, 2007).

Keunggulan dari metode AHP dalam pengambilan keputusan yaitu pada proses membandingkan setiap kriteria yang telah ditetapkan dalam suatu permasalahan sehingga diperoleh suatu bobot nilai dari kriteria yang telah ditetapkan. Sehingga sistem ini mampu memberikan hasil perhitungan yang ditampilkan dalam bentuk perankingan dengan cara mengurutkan nilai dari nilai yang terbesar hingga nilai yang terkecil.

Proses perhitungan AHP yaitu memasukkan nilai matrik, melakukan proses normalisasi matrik, menginput bobot supplier, melakukan proses perkalian antara nilai prioritas kriteria dengan nilai prioritas supplier (T.L. Saaty \& Vargas, 2000).

\subsection{Analisis Tata Cara Penilaian AHP}

Pada simulasi penilaian kinerja karyawan diambil penilaian kinerja terhadap prestasi kinerja perawat yang menjadi sampel dalam penelitian ini. Pada Proses AHP berikut ini ada 6 kriteria penilaian yang digunakan dan disimbolkan sebagai C1 sampai dengan C6. Adapun kriteria penilaian sebagai berikut :

$$
\begin{aligned}
& \mathrm{C} 1=\text { Profesionalitas } \\
& \text { C2 }=\text { Kinerja } \\
& \text { C3 }=\text { Attitude } \\
& \text { C4 }=\text { Leadership } \\
& \text { C5 }=\text { Loyalitas }
\end{aligned}
$$

$$
\text { C6 = Komunikasi }
$$

Berikut ini Skala Perbandingan untuk menentukan prioritas kriteria. Skala Penilaian yang digunakan adalah skala Likert.

Keterangan :

$$
\begin{array}{ll}
5 & =\text { Sangat Baik } \\
4 & =\text { Baik } \\
3 & =\text { Cukup } \\
2 & =\text { Kurang } \\
1 & =\text { Sangat Kurang. }
\end{array}
$$

Penggunaan metode AHP dalam menyelesaikan permasalahan menggunakan beberapa prinsip dasar, diantaranya adalah :

\section{a. Membuat Hierarki}

Sistem yang kompleks dan rumit dapat dengan mudah dipahami dengan membaginyamenjadi beberapa elemen pendukung, dilanjutkan dengan penyusunan elemen-elemen secara hierarki, dan kemudian dilakukan proses penggabungan.

b. Penilaian Kriteria dan Alternatif

Dilakukan proses perbandingan berpasangan antara kriteria-kriteria yang digunakan dan alternative untuk menyelesaikan berbagai persoalan, skala 1 sampai dengan 9 merupakan skala terbaik untuk mengekspresikan pendapat. Nilai dan definisi pendapat kualitatif dari skala perbandingan dapat di ukur menggunakan tabel analisis pada tabel 1 .

\section{Tabel 1. Skala Penilaian}

\begin{tabular}{lll}
\hline & $\begin{array}{l}\text { Nil } \\
\text { ai }\end{array}$ & $\begin{array}{l}\text { Nilai } \\
\text { IR }\end{array}$ \\
\hline & 9 & 1.45 \\
Lebih diutamakan menuju sangat diutamakan & 8 & 1.41 \\
Lebih diutamakan & 7 & 1.32 \\
Diutamakan menuju lebih diutamakan & 6 & 1.24 \\
Diutamakan & 5 & 1.12 \\
Cukup diutamakan menuju diutamakan & 4 & 0.90 \\
Cukup diutamakan & 3 & 0.58 \\
Setara menuju cukup diutamakan & 2 & 0.00 \\
Setara & 1 & 0.00 \\
\hline
\end{tabular}


Langkah proses dalam tata cara menerapkan metode AHP yaitu:

1. Penentuan prioritas kriteria / Synthesis of Priority

Langkah yang dilakukan untuk menentukan prioritas kriteria adalah :

a. Membuat Matriks Berpasangan

Dilakukan penilaian perbandingan antara satu kriteria dengan kriteria yang lain : Untuk melakukan penilaian terhadap tabel matriks berpasangan sepertimpada tabel 2, nilai yang diambil berdasarkan tabel 1 skala penilaian

Tabel 2. Matriks Berpasangan

\begin{tabular}{lllllll}
\hline KRITERIA & C1 & C2 & C3 & C4 & C5 & C6 \\
\hline $\begin{array}{l}\text { Profesionalit } \\
\text { as }\end{array}$ & 1 & 9 & 8 & & 6 & 5 \\
Kinerja & 0,11 & 1 & 8 & 7 & 6 & 5 \\
Attitude & 0,13 & 0,13 & 1 & 7 & 6 & 5 \\
Leadership & 0,14 & 0,14 & 0,14 & 1 & 6 & 5 \\
Loyalitas & 0,17 & 0,17 & 0,17 & 0,17 & 1 & 5 \\
Komunikasi & 0,20 & 0,20 & 0,20 & 0,20 & 0,20 & 1 \\
Jumlah & $\mathbf{1 , 7 5}$ & $\mathbf{1 0 , 6 3}$ & $\mathbf{1 7 , 5 1}$ & $\mathbf{2 2 , 3 7}$ & $\mathbf{2 5 , 2 0}$ & $\mathbf{2 6 , 0 0}$ \\
\hline
\end{tabular}

b. Menentukan Matriks Nilai Kriteria

Matriks ini diperoleh dengan rumus :

Matriks Kriteria $=$ Nilai baris kolom sebelumnya / jumlah masing- masing kolom sebelumnya.

\section{Tabel 3. Matriks Nilai Kriteria}

\begin{tabular}{lllllllll}
\hline KRITERIA & C1 & C2 & C3 & C4 & C5 & C6 & $\begin{array}{l}\text { Ju } \\
\text { ml } \\
\text { ah }\end{array}$ & $\begin{array}{l}\text { Prio } \\
\text { rita } \\
\text { s }\end{array}$ \\
\hline Profesionalitas & 0,5 & 0,8 & 0,4 & 0,3 & 0,2 & 0,1 & 2,6 & 0,44 \\
& 7 & 5 & 6 & 1 & 4 & 9 & 2 & \\
Kinerja & 0,0 & 0,0 & 0,4 & 0,3 & 0,2 & 0,1 & 1,3 & 0,23 \\
& 6 & 9 & 6 & 1 & 4 & 9 & 6 & \\
Attitude & 0,0 & 0,0 & 0,0 & 0,3 & 0,2 & 0,1 & 0,8 & 0,15 \\
& 7 & 1 & 6 & 1 & 4 & 9 & 8 & \\
Leadership & 0,0 & 0,0 & 0,0 & 0,0 & 0,2 & 0,1 & 0,5 & 0,10 \\
& 8 & 1 & 1 & 4 & 4 & 9 & 8 & \\
Loyalitas & 0,1 & 0,0 & 0,0 & 0,0 & 0,0 & 0,1 & 0,3 & 0,06 \\
& 0 & 2 & 1 & 1 & 4 & 9 & 6 & \\
Komunikasi & 0,1 & 0,0 & 0,0 & 0,0 & 0,0 & 0,0 & 0,2 & 0,03 \\
\hline
\end{tabular}

Nilai pada kolom jumlah didapat dengan cara menjumlahkan nilai pada kolom kriteria, sedangkan nilai kolom prioritas diperoleh dengan membagikan nilai jumlah terhadap jumlah kriteria Profesionalitas

$0,57+0,85+0,46+0,31+0,24+0,19=2,62$

Kinerja

$0,06+0,09+0,46+0,31+0,24+0,19=1,36$

Attitude

$0,07+0,01+0,06+0,31+0,24+0,19=0,88$

Leadership

$0,08+0,02+0,01+0,01+0,04+0,19=0,58$

Loyalitas

$0,10+0,02+0,01+0,01+0,04+0,19=0,36$

Komunikasi

$0,11+0,02+0,01+0,01+0,01+0,04=0,20$

Sedangkan nilai kolom prioritas berasal dari pembagian nilai jumlah dengan jumlah kriteria

Profesionalitas $=2,62 / 6=0,44$

Kinerja $=1,36 / 6=0,23$

Attitude $=0,88 / 6=0,15$

Leadership $=0,36 / 6=0,10$

Loyalitas $=0,20 / 6=0,06$

Komunikasi $=0,15 / 6=0,03$

c. Menentukan Matriks Penjumlah Setiap Baris.

Matriks tabel 4 ini diperoleh dengan cara mengalikan nilai prioritas pada tabel 3 dengan matriks berpasangan tabel.untuk mendapatkan nilai jumlah setiap baris dilakukan perkalian nilai nilai prioritas tabel 3. (0.44) pada baris Profesionalitas dengan tabel.1 pada kolom C1.

d. Menentukan Perhitungan Rasio Konsistensi Dalam membuat keputusan, sangatlah penting untuk mengetahui seberapa baik nilai konsistensi yang ada karena kita menginginkan 
keputusan berdasarkan konsistensi yang tinggi. Adapun tahapan yang harus dilakukan untuk mendapatkan rasio konsistensi adalah sebagai berikut:

a. Lakukan perkalian setiap nilai pada kolom pertama dengan prioritas relatif elemen pertama, selanjutnya nilai pada kolom kedua dengan prioritas relatif elemen kedua dan begitu pula nilai kolom berikutnya.

b. Lakukan penjumlahan setiap baris.

c. Dari Hasil dari penjumlahan baris kemudian dibagi dengan elemen prioritas relatif yang bersangkutan.

Tabel 4. Matriks Penjumlahan Tiap Baris

\begin{tabular}{llllllll}
\hline $\begin{array}{l}\text { KRITER } \\
\text { IA }\end{array}$ & C1 & C2 & C3 & C4 & C5 & C6 & $\begin{array}{l}\text { Juml } \\
\text { ah }\end{array}$ \\
\hline $\begin{array}{l}\text { Profesion } \\
\text { alitas }\end{array}$ & 0,44 & 2,04 & 1,18 & 0,67 & 0,36 & 0,17 & 4,85 \\
Kinerja & 0,05 & 0,23 & 1,18 & 0,67 & 0,36 & 0,17 & 2,66 \\
$\begin{array}{l}\text { Attitude } \\
\text { Leader }\end{array}$ & 0,05 & 0,03 & 0,15 & 0,67 & 0,36 & 0,17 & 1,43 \\
ship & 0,06 & 0,03 & 0,02 & 0,10 & 0,36 & 0,17 & 0,74 \\
$\begin{array}{l}\text { Loyalitas } \\
\text { Komuni } \\
\text { kasi }\end{array}$ & 0,07 & 0,04 & 0,02 & 0,02 & 0,06 & 0,17 & 0,38 \\
\hline
\end{tabular}

Kemudian lakukan proses penjumlahan

hasil bagian yang diperoleh diatas dengan banyak elemen yang ada, sehingga diperoleh nilai yang disebut dengan alpha maks. Perhitungan ini bertujuan untuk memastikan bahwa nilai rasio konsistensi yang diperoleh ( $C R$ $<=0,1)$, jika ternyata nilai dari $C R$ atau Rasio Konsistensi lebih besar dari 0,1 maka matriks perbandingan berpasangan yang dibuat harus diperbaiki.

Tabel 5. Matriks Penjumlahan Tiap baris

\begin{tabular}{llll}
\hline & Jumlah & Prioritas & Hasil \\
\hline Profesionalitas & 4,85 & 0,44 & 5,29 \\
Kinerja & 2,66 & 0,23 & 2,88 \\
Attitude & 1,43 & 0,15 & 1,58 \\
Leadership & 0,74 & 0,10 & 0,84 \\
Loyalitas & 0,38 & 0,06 & 0,44 \\
Komunikasi & 0,23 & 0,03 & 0,26 \\
\hline
\end{tabular}

Kolom Jumlah pada Kriteria Attitude didapat dari kolom jumlah baris Attitude pada tabel 3, sedangkan Kolom Prioritas Attitude didapat pada kolom prioritas baris Attitude pada tabel 2. Dari tabel 5. didapat nilai-nilai sebagai berikut :

Jumlah (Hasil Penjumlahan dari nilai-nilai tiap baris hasil) $=5,29+2,88+1,58+0,84+0,44+$ $0,26=11,28$

$\mathrm{n}($ jumlah kriteria $)=6$

Maks (jumlah/n) $=11,28 / 6=1,88$

$\mathrm{CI}(($ maks-n) $) / \mathrm{n})=(1,88-6) / 6=-0,68$

$\mathrm{CR}(\mathrm{CI} / \mathrm{IR}$ lihat tabel 2$)=-0,51$

Hasil CR diperoleh sebesar $-0.51<0.1$ maka rasio kensistensi sehingga hasil perhitungan dapat diterima. Dari hasil perhitungan maka diperoleh :

Tabel 6.Matriks Hasil

\begin{tabular}{lcccccc}
\hline Pilihan & C1 & C2 & C3 & C4 & C5 & C6 \\
\hline $\begin{array}{llllll}\text { Prioritas } \\
\text { (W) }\end{array}$ & 0,44 & 0,23 & 0,15 & 0,10 & 0,06 & 0,03 \\
Sangat & 5,00 & 5,00 & 5,00 & 5,00 & 5,00 & 5,00 \\
Baik & 4,00 & 4,00 & 4,00 & 4,00 & 4,00 & 4,00 \\
Baik & 2,00 & 2,00 & 2,00 & 2,00 & 2,00 & 2,00 \\
Cukup & 2,00 & 2,00 & 2,00 & 2,00 & 2,00 & 2,00 \\
Kurang & 1,00 & 1,00 & 1,00 & 1,00 & 1,00 & 1,00 \\
$\begin{array}{l}\text { Sangat } \\
\text { Kurang }\end{array}$ & & & & & & \\
\hline
\end{tabular}

Dengam metode AHP dengan 6 kriteria penilaian diatas dalam skala penilaian kriteria syarat seorang perawat terbaik memiliki nilai kriteria Profesionalitas yang sangat diutamakan, selain kinerja, attitude, leadership, loyalitas dan komunikasi.

\subsection{PENELITIAN YANG TERKAIT}

Pada penelitian sebelumnya yang dilakukan oleh Stefanie.G.N.L.Worang, 2013 dengan judul Penerapan Metode 360 Derajat dalam Sistem Pendukung Keputusan Penentuan Jurusan SMA 
Berbasis Web (S.G.N.L, 2013), pada penelitian tersebut peneliti menghasilkan sebuah sistem pendukung keputusan dalam membantu siswa mengambil keputusan dalam mengambil jurusan di sekolah. Pada sistem tersebut siswa dapat mengakses angket secara real time dan diinput oleh siswa itu sendiri dan orang tua mereka, pada proses input nilai mata pelajaran dilakukan oleh guru Bimbingan Konseling, sehingga menghasilkan nilai psikotes untuk proses penjurusan siswa tersebut.

Pada penelitian Arini Widyowati, 2010 dengan judul Penerapan Sistem Penilaian Kinerja 360 Derajat Sebagai Usaha Meningkatkan Persepsi Positif terhadap Keadilan Prosedural Penilaian kinerja (Widyowati, 2010), dari hasil penelitian diketahui bahwa bahwa pada sistem penilaian kinerja 360 derajat dinilai sangat efektif dalam meningkatkan persepsi positif sebesar $78,8 \%$ pada prosedur penilaian kinerja. Pada proses evaluasi kognitif penilaian dengan metode 360 derajat menghasilkan data hasil dalam proses penilaian kinerja yang lebih akurat dan lengkap .

Menurut penelitian Adhy Purnama, 2015 dengan judul Sistem Pendukung Keputusan Pemilihan Pejabat Kopertis Wilayah III Menggunakan Metode Analytic Hierarchy Process (Adhy Purnama, 2015), Pada Penelitian Metode AHP digunakan untuk menganalisa dan memberikan solusi dalam proses pemilihan Pejabat Kopertis Wilayah III yang pada saat itu berdasarkan faktor subyektif dan masih konvensional. Pada metode AHP (Analytical Hierarchy Process) ini pengambilan data dilakukan melalui proses wawancara dan pemberian kuisioner. Hasil penelitian menunjukkan bahwa nilai skor kriteria tertinggi sebesar 0,409 untuk menjadi pejabat di lingkungan Kopertis Wilayah III, berdasarkan kriteria yang telah ditetapkan berupa kemampuan manajerial, kualitas kerja, skill dan pengetahuan , tanggung jawab, komunikasi, disiplin kerja, kerjasama, motivasi kerja.

Penelitian ini merupakan penggabungan kedua metode penelitian terdahulu diatas sehingga diperoleh nilai kinerja pegawai di perusahaan yang diperoleh dari penilaian yang diberikan seluruh karyawan yang terlibat dibagian tempat yang diadakan penilaian kinerja pegawai perusahaan berdasarkan kriteria prioritas yang diinginkan perusahaan.

\section{HASIL DAN PEMBAHASAN}

Penelitian ini menghasilkan suatu aplikasi sistem informasi penilaian kinerja perawat pada Rumah Sakit Fadhilah menggunakan metode 360 derajat dalam proses penginputan data dan dengan metode penilaian dari Analytic Hierarchy Process (AHP) pada proses perankingan. Hasil dari penelitian ini dituangkan dalam bentuk sistem aplikasi yang dijalankan dijaringan localhost yang nantinya juga menghasilkan suatu sistem yang dapat digunakan untuk mempermudah pihak manajemen perusahaan dalam studi kasus penelitian ini rumah sakit Fadilah untuk menentukan hasil kinerja perawat terbaik yang sesuai dengan kriteria capaian syarat untuk menjadi kepala perawat yang diharapkan. Penyajian informasi menggunakan sistem aplikasi yang menghasilkan informasi yang lebih akurat, cepat, serta tidak terjadi perulangan dalam proses 
penginputan data. Adapun tampilan hasil dari sistem aplikasi yang dibuat adalah sebagai berikut:

\section{1) Halaman Form Log in}

Halaman form log in merupakan Halaman yang akan digunakan user untuk ingin masuk ke menu utama yang berfungsi agar tidak setiap user dapat mengakses sistem ini. Berikut Halaman form log in.

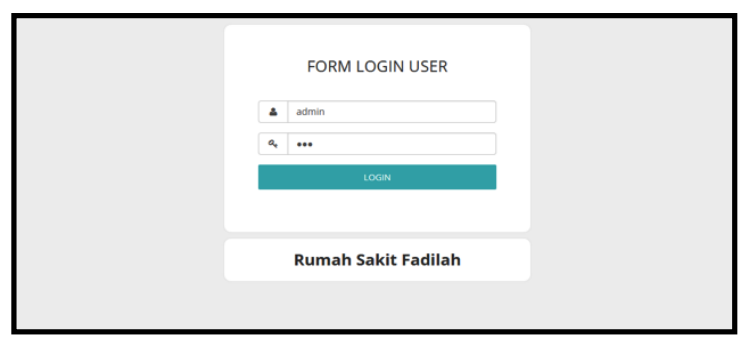

\section{Gambar 2. Halaman Form Log in}

\section{2) Halaman Menu}

Halaman menu utama merupakan Halaman yang berfungsi untuk menghubungkan antara halaman satu dengan yang lain, Terdiri dari halaman menu admin dan menu tim penilai meluputi kepala rumah sakit, kepala perawat, rekan kerja dan menu perawat.

\section{3) Halaman Menu Admin}

Setelah melakukan log in pada sistem ini akan menampilkan menu admin, yang akan digunakan untuk memasukkan data perawat dan dapat melihat hasil penilaian prestasi kinerja perawat.

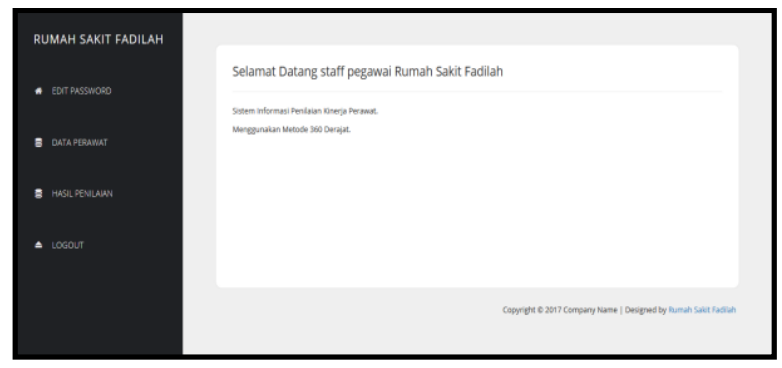

Gambar 3. Halaman Menu Admin
4) Halaman Menu Tim Penilai

Metode 360 derajat digunakan pada halaman menu ini yang merupakan halaman tim penilai terdiri dari meluputi kepala rumah sakit, kepala perawat, rekan kerja dan menu perawat, dimana masing-masing dapat melakukan penilaian terhadap kinerja perawat yang akan dinilai, sehingga semua karyawan yang berada di unit kerja tersebut dapat memberikan penilaian .

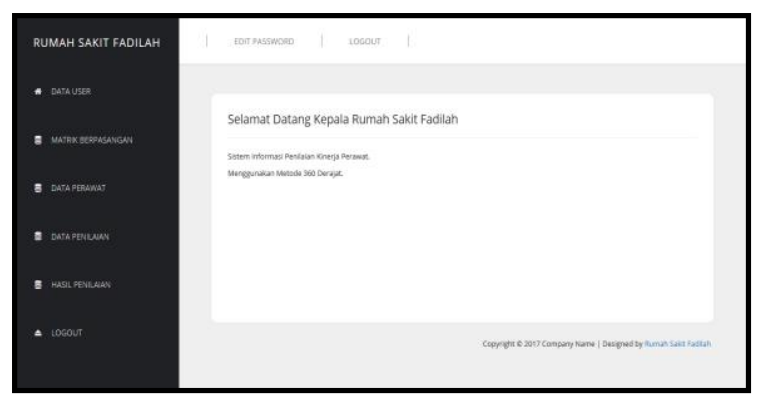

\section{Gambar 4. Halaman Menu Tim Penilai}

5) Halaman Data Perawat

Pada halaman ini berfungsi untuk memasukkan data perawat kedalam sistem, kemudian hasil penginputan akan ditampilkan dalam bentuk daftar.

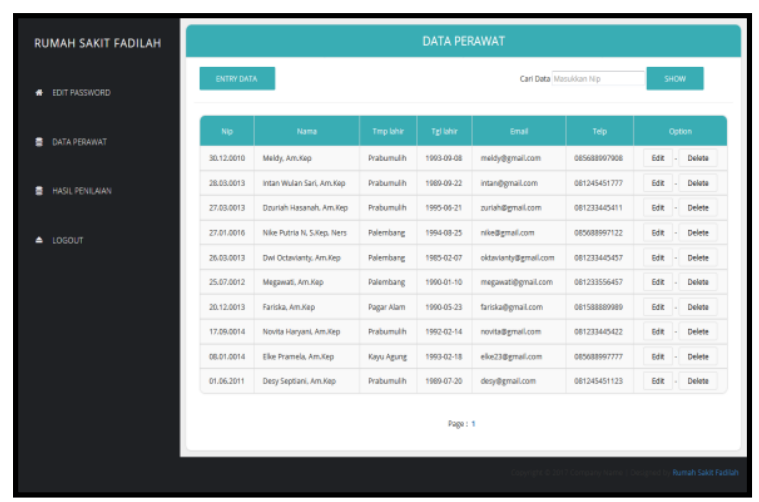

\section{Gambar 5. Halaman Data Perawat}

6) Halaman Entry Perawat

Syarat untuk memasukkan data perawat dapat dilakukan pada halaman entry perawat dengan menentukan nip, nama perawat, tempat dan tanggal lahir, alamat, telp, email, username dan password. 


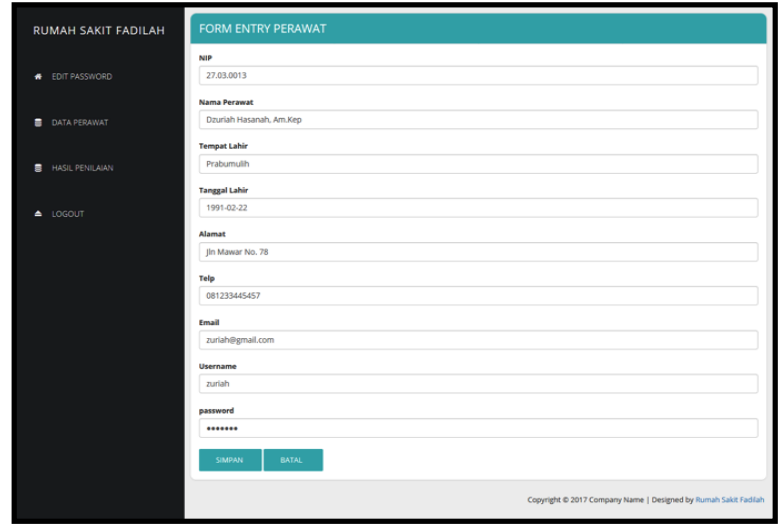

Gambar 6. Halaman entry Perawat

7) Halaman Penilaian Nilai Kriteria

Pada halaman penilaian nilai kriteria akan digunakan tim penilai untuk melakukan penilaian terhadap prestasi kinerja perawat, dimana pada halaman ini dapat diakses oleh kepala rumah sakit, kepala perawat, rekan kerja dan perawat. Halaman ini dapat dilihat pada gambar 8 .

8) Halaman Matrik Berpasangan

Halaman ini berfungsi untuk menampikan data matrik berpasangan pada kriteria penilaian, kemudan data tersebut akan dihubungkan pada halaman proses AHP.

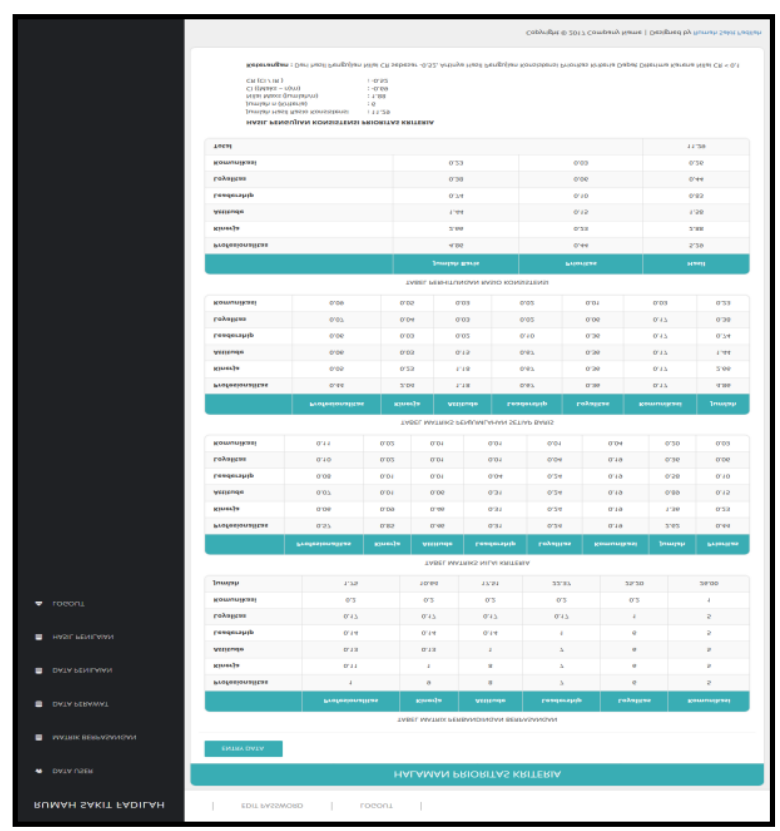

Gambar 7. Halaman Matrik Berpasangan

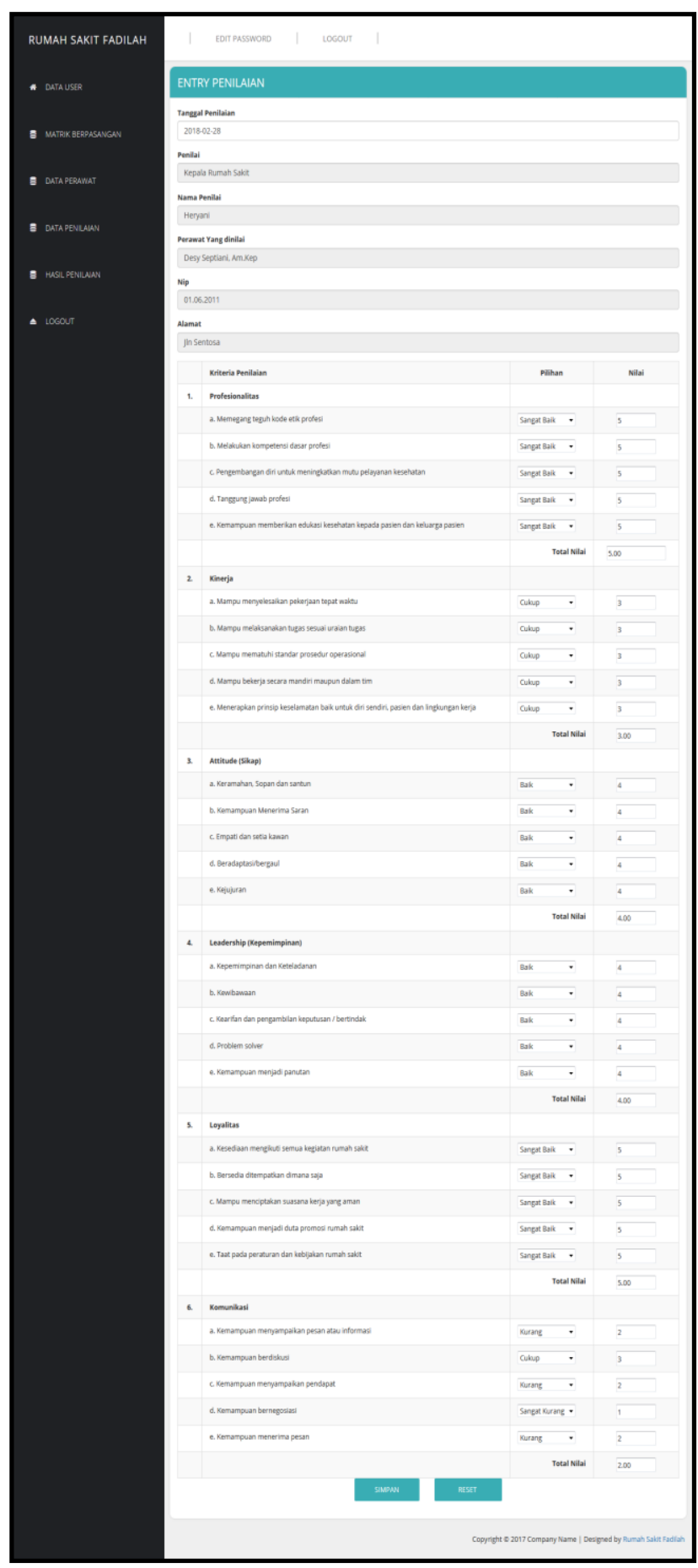

\section{Gambar 8 .Halaman Penilaian Nilai Kriteria}

9) Halaman Entry Prioritas Kriteria

Proses memasukkan data Entry Prioritas kriteria dilakukan pada halaman matrik berpasangan, dengan menentukan nilai pada 
pilihan jawaban. Halaman entry prioritas kriteria penilaian dapat dilihat pada gambar 9 .

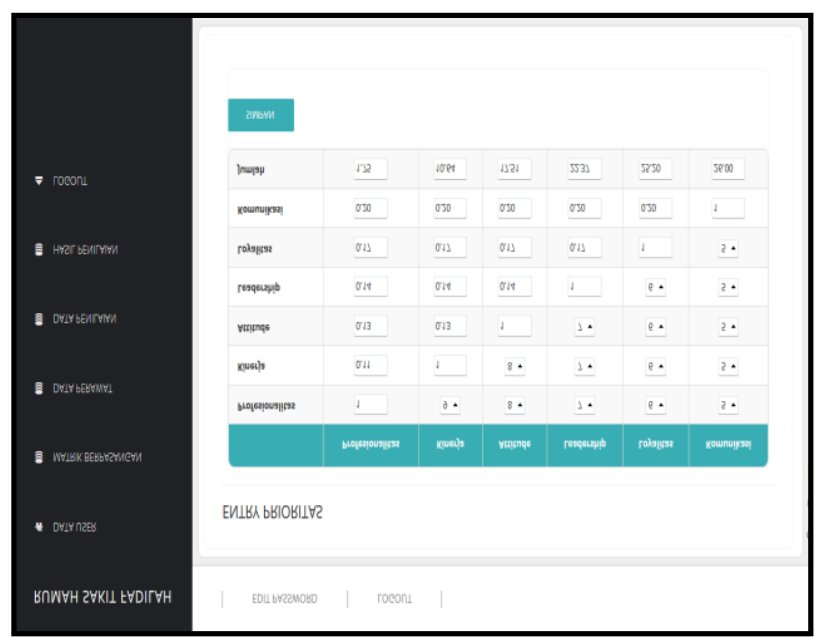

\section{Gambar 9. Halaman Entry Prioritas Kriteria}

10) Halaman Data Penilaian

Setelah data nilai kriteria dan data prioritas kriteria diperoleh, maka selanjutnya data tersebut akan diproses pada halaman proses AHP, dimana hasil akhir dari penilaian akan menampilkan daftar perengkingan nilai perawat dari tertinggi sampai terendah.

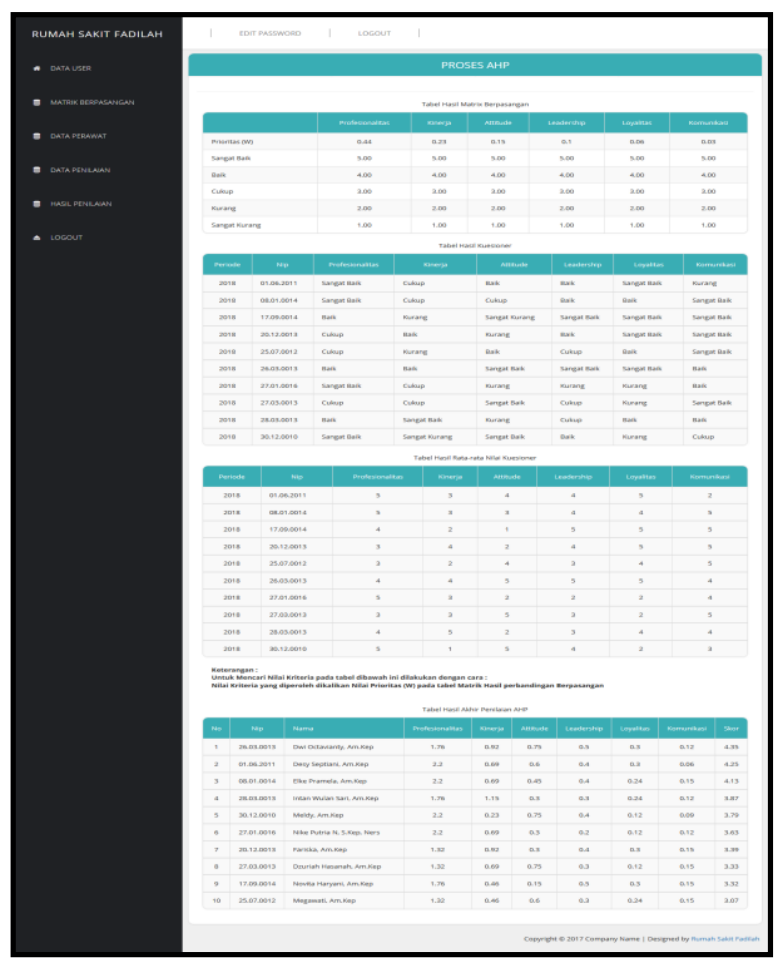

Gambar 10. Halaman Data Penilaian
11) Halaman hasil Akhir penilaian

Halaman ini merupakan halaman yang digunakan untuk menampilkan hasil penilaian akhir, menampilkan informasi skor perangkingan nilai tertinggi sampai terendah.

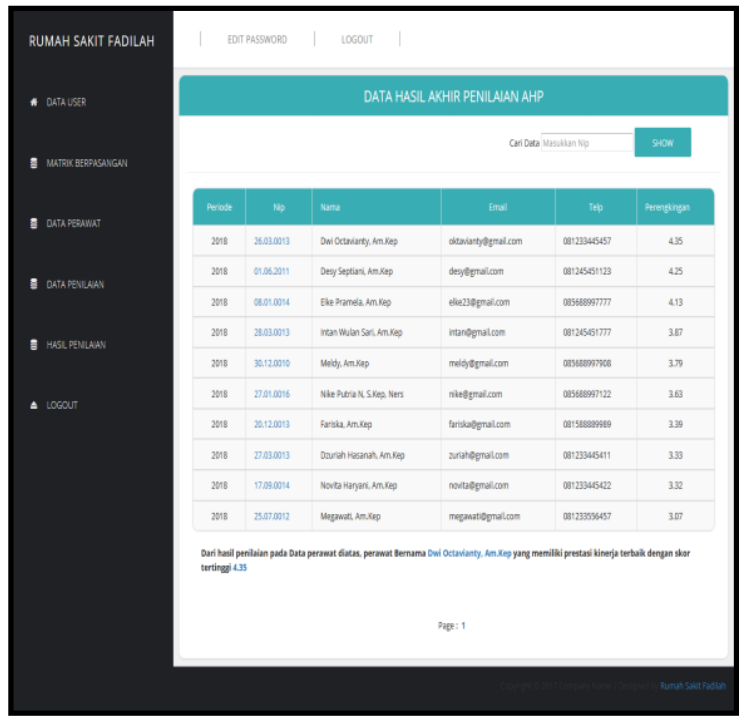

Gambar 11. Halaman Hasil Akhir Penilaian

12) Halaman Rincian Penilaian

Pada halaman ini berfungsi untuk menampilkan rincian penilaian dari setiap perawat, dimana kita dapat mengetahui siapa saja tim penilai yang sudah melakukan penilaian terhadap perawat yang bersangkutan.

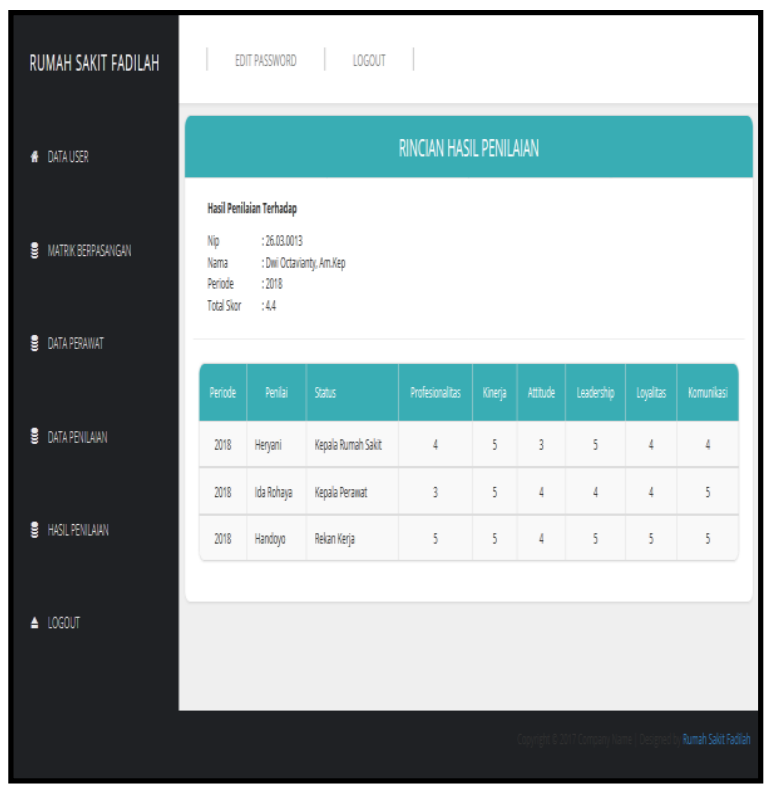

Gambar 12. Halaman Rincian Penilaian 


\section{SIMPULAN}

Penerapan metode 360 Derajat dalam sistem perangkat lunak penilaian kinerja karyawan pada sebuah perusahaan sangat efektif untuk mendapatkan penilaian dari banyak pihak baik dari atasan, rekan kerja, bawahan, maupun konsumen sehingga penilaian menjadi lebih objektif, dengan menggabungkan proses pengambilan nilai kriteria menggunakan nilai rata-rata untuk dihitung menggunakan metode AHP sangat baik sekali karena dengan cara membandingkan setiap kriteria yang dimiliki oleh suatu penilaian yang diinginkan akan menghasikan suatu bobot nilai dari setiap kriteria yang ada, sehingga sistem ini mampu memberikan hasil perhitungan yang ditampilkan dalam bentuk perankingan dengan cara mengurutkan dari nilai yang terbesar hingga nilai yang terkecil yang hasil penilaiannya sesuai dengan skala prioritas kriteria yang diinginkan perusahaan.

Dengam perhitungan dengan metode AHP yang mengambil 6 kriteria penilaian, dimana dalam studi kasus mengambil penilaian kinerja perawat di Rumah Sakit Fadilah dapat terlihat bahwa untuk skala penilaian kriteria seorang perawat terbaik dipilih kriteria Profesionalitas yang sangat diutamakan, selain kinerja, attitude, leadership, loyalitas dan komunikasi dari penentuan tersebut didapat bahwa, dengan penentuan nilai Profesionalitas yang diutamakan perawat yang memiliki nilai profesionalitas tertinggi dan menyusul nilai-nilai kriteria lain yang dibandingkan setelahnya yang akan menduduki ranking pertama penilaian.

\section{DAFTAR PUSTAKA}

Adhy Purnama. (2015). Sistem Pendukung Keputusan Pemilihan Pejabat Kopertis Wilayah Iii Menggunakan Metode Analytic Hierarchy Process. Jurnal Penelitian Humaniora, 20, 18-29.

Ali Hasan, SMn., M. ., \& Universitas, D. (2013). Penilaian Kinerja Pegawai dengan Metode 360 Degrees Feedback. Retrieved from https://www.scribd.com/doc/161842189/Pen ilaian-Kinerja-Dengan-Metode-360-Derajat

Antonioni, D. (1996). Designing an effective 360degree appraisal feedback process. Organizational Dynamics. https://doi.org/10.1016/S00902616(96)90023-6

Beehr, T. A., Ivanitskaya, L., Hansen, C. P., Erofeev, D., \& Gudanowski, D. M. (2001). Evaluation of 360 degree feedback ratings: Relationships with each other and with performance and selection predictors. Journal of Organizational Behavior, 22, pp.775-784. https://doi.org/10.1002/job.113

deLeon, L., \& Ewen, A. J. (1997). Multi-Source Performance Appraisals: Employee Perceptions of Fairness. Review of Public Personnel Administration, 17(1), 22-36. https://doi.org/10.1177/0734371X97017001 03

Fleenor, J. W., \& Prince, J. M. (1997). Using 360-Degree Feedback in Organizations An Annotated Bibliography. North Carolinahttps://pdfs.semanticscholar.org/54 dc/adff45d3cb7ab29303e4f69ce71c3b17874 6.pdf: Center for Creative Leadership ,Greensboro, North Carolina. Retrieved from

https://pdfs.semanticscholar.org/54dc/adff45 d3cb7ab29303e4f69ce71c3b178746.pdf

Kreitner, R., \& Kinicki, A. (2001). Organizational Behavior. In Fifth Edition" New York, Mc Grow-Hill Company,Inc. https://doi.org/10.1016/01678760(91)90022-P

Kusrini. (2007). Konsep dan Aplikasi Sistem Pendukung Keputusan. Andi Offset.Yogyakarta. 
Linman, T. (2006). 360-degree Feedback. Weighing the Pros and Cons.

Paré, G., Tremblay, M., \& Lalonde, P. (2004). The impact of human resources practices on IT personnel commitment, citizenship behaviors, and turnover intentions. The Twenty First InternationalSocial Justice Research, 17, 3-21,.

S.G.N.L, W. (2013). Penerapan Metode 360 Derajat dalam Sistem Pendukung Keputusan Penentuan Jurusan SMA Berbasis Web. In Proceding Seminar Nasional Aplikasi Teknologi Informasi, ISSN1907-9022, 2013. (pp. 40-50). Retrieved from https://media.neliti.com/media/publications/ 174840-ID-penerapan-metode-360-derajatdalam-siste.pdf

Saaty, T. L. (1980). The Analytic Hierarchy Process. McGraw-Hill, New York. https://doi.org/10.3414/ME10-01-0028

Saaty, T. L., \& Vargas, L. (2000). Fundamentals of Decision Making and Priority Theory With the Analytic Hierarchy Process. RWS Publications.

Tziner, A., Joanis, C., \& Murphy, K. R. (2000). A comparison of three methods of performance appraisal with regard to goal A Comparison Of Three Methods of Performance Appraisal With Regard To Goal Properties, Goal Perceptions \& Ratee Satisfaction. Group \& Organization Management, 25(2), 175-190.

Widyowati, A. (2010). penilaian-kinerja-360derajat-sebagai-usaha-meningkatkanpersepsi-positif-terhadap Keadilan Prosedural Penilaian Kinerja. Jurnal Humanitas, 7(No.1), 89-100. Retrieved from http://eprints.uad.ac.id

Yamaguchi, I. (2005). Interpersonal communication tactics and procedural justice for uncertainty management of Japanese workers. Journal of Business Communication, 42(2), pp.168-194,. https://doi.org/10.1177/0021943605274600 